\title{
Contradictions and power play in service encounters: an activity theory approach ${ }^{1}$
}

\section{Contradições e jogo de poder na prestação de serviços: abordagem de teoria da atividade}

\author{
Mario Eduardo Giraldo Oliveros ${ }^{2}$ \\ Susan Vaux Halliday ${ }^{3}$ \\ Maria Mercedes Botero Posada ${ }^{4}$ \\ Reinhard Bachmann ${ }^{5}$
}

\begin{abstract}
We present a perspective on the interpersonal element of service in which economic and social collaboration takes place in real time: the service encounter. We view it as a site of conflict for power and control where social identities are anchored and collective meanings are constituted and reproduced. Our theoretical underpinning is taken from the Activity Theory (AT) to shed light on the service encounter as a contradictory, political locus of tension between providers and customers (internal and external) in the Higher Education (HE) market.
\end{abstract}

Keywords: Service Encounter, Activity Theory, Activity System, Power, Service Dominant Logic, Contradictions.

\section{Resumo}

Neste trabalho apresenta-se uma perspectiva sobre o elemento interpessoal do serviço em que a colaboração econômica e social é realizada em tempo real: o encontro de serviço. Visto como um local de conflito de poder e controle social, no qual as identidades são ancoradas e significados coletivos são constituídos e reproduzidos. O referencial teórico deste trabalho baseia-se na Teoria da Atividade (TA), que permite compreender melhor o encontro de serviços como um locus político de tensão contraditório entre fornecedores e clientes (internos e externos) no mercado de Ensino Superior (ES).

Palavras-chave: Encontro de Serviço, Teoria da Atividade, Sistema de Atividade, Poder, Lógica Dominante de Serviço, Contradições.

\footnotetext{
Paper received in April 2010 and accepted for publication in June 2010.

${ }^{1}$ A preliminary version of this article was presented in the LAEMOS2010 Conference "Constructing and Disrupting Social Realities: Tales of Development and Crisis in Markets, Institutions and Organizations" in the Sub-Theme of Power, Organizations and Institutional Change.

${ }^{2}$ Profesor Asistente, Escuela de Negocios, Universidad del Norte, Colombia. PhD Student in Management, University of Surrey, UK; Especialista en Psicología Económica y del Consumo, Universidad del Norte, Colombia; Maestro en Mercadotecnia, EGADE ITESM, Mexico; Administrador de Empresas, Universidad Externado de Colombia, Colombia. Km5 Via a Puerto Colombia, Escuela de Negocios, Univ. del Norte, Barranquilla, Colombia. E-mail: mgiraldo@uninorte.edu.co

${ }^{3}$ Senior Lecturer in Marketing, University of Surrey, UK; PhD in Marketing, University of Bradford, UK; MBA, London School of Economics, UK; MA, Cantab, UK; BA in History, University of Cambridge, UK.

Room 25MS02, School of Management, University of Surrey, Guildford, Surrey, UK GU2 7XH

E-mail: S.Halliday@surrey.ac.uk

${ }^{4}$ Profesor Asistente, Dpto. de Psicología, Universidad del Norte, Colombia. Estudiante de Doctorado en Psicología, Universidad del Norte, Colombia; Magíster en Estudios Políticos y Económicos, Universidad del Norte, Colombia; Especialista en Psicología Clínica, Universidad del Norte, Colombia; Psicologa, Universidad del Norte, Colombia. Km5 Via a Puerto Colombia, Dpto de Psicología, Univ. del Norte, Barranquilla, Colombia.

E-mail: mmbotero@uninorte.edu.co

${ }^{5}$ Professor of Strategic Management, University of Surrey, UK. PhD in Sociology, University of Dortmund, Germany; Postgraduate Studies in Sociology, University of Erlangen-Nuremberg, Germany; BA in Sociology, Political Science, German Literature, Linguistics and History, University of ErlangenNuremberg, Germany. Room 55MS03, School of Management, University of Surrey, Guildford, Surrey, UK GU2 7XH.

E-mail: R.Bachmann@surrey.ac.uk
} 
We present a perspective on the interpersonal element of service where economic and social collaboration takes place in real time: the service encounter. We view it as a site of conflict for power and control where social identities are anchored and collective meanings are constituted and reproduced. Our theoretical underpinning is taken from Activity Theory (AT) to shed light on the service encounter as a contradictory, political locus of tensions between providers and customers (internal and external) in the Higher Education (HE) market. Educational institutions and organizations have increasingly come under pressure, and because of that, their instrumental and symbolic roles are called into question; their sense making function is jeopardized; and they have a hard time in fulfilling their purposes. These generalities apply to HE institutions in Colombia. Therefore, we draw upon activity theory to explore serious barriers to collaboration for value actualization in service encounters in the particularly unstable and risky world of HE provision in Colombia. This value actualization is the core business for HE; understanding better these service encounters will enable HE institutions in Colombia to develop.

We focus on AT as a framework for understanding the service encounter and explain how power and political behavior have impact as barriers or facilitators for value actualization in service encounters in one Colombian HE institution. AT provides a framework of interactive elements from which development emerges. The activity system is the unit of measure of activity theory and includes the subject(s) who are the doer(s) of the activity (e.g. students, academics, secretaries, administrators); the object, the transformation of which is the aim of the activity (e.g. curriculum design, a solution to an inquiry, scientific understanding, vocational instruction); and the community, which is the group of actors who share a particular object (e.g. psychology students, finance academics, board of directors). The relationships among these elements are mediated by the artifacts (e.g. practices, procedures, teaching materials); the division of labor (e.g. task specialization, job roles, power); and the rules (e.g. cultural norms, organizational guidelines and standards, classroom rules, political behavior). Since organizational activities can be considered as open systems equilibrium is an exception, therefore, contradictions and disruptions are fundamental ingredients of the activity system which can also be known as a disturbance-producing system; these contradictions produce incoherencies, inconsistencies, tensions, and paradoxes, but also novel efforts to transform the activity. We use third generation of AT, in which two or more activity systems come into contact, to explore the perspective of multiple actors in the HE environment.

Our aim was to generate a number of narratives from those members of the institution at the cutting-edge of service delivery. Due to the presence of distrust and negative power we generated one narrative and also some question/answer responses. We found barriers to collaboration are caused by lack of clarity and coherence in processes, inflexible bureaucratic rules, highly fragmented division of labor, lack of knowledge and recognition about practices, scripts, plans, and procedures. These barriers were present in the HE institution studied; we believe they affect collaboration for value actualization in service encounters, and potentially hinder institutional development in HE in Colombia.

\section{Introduction}

Our study proposes the HE experience as a group of highly related and collaborative human activities in which the main activity or core service is the co-created learning experience activity of its actors. This is the area of value that can be actualized more in real time via the service encounter. Currently the customer/provider cocreation of value is centre-stage in the service-dominant logic approach to marketing theory -SD Logic(VARGO; LUSCH, 2004, 2006, 2008a). We use AT as we focus on the service encounter. This gives us a sufficiently complex and dynamic theoretical frame to, in turn; provide a more comprehensive understanding of the service encounter. For example, a service provider, aims to offer a differentiated value proposition to the market (object) to obtain competitive advantage (outcome); this value proposition is transformed by the interaction of the different actors and networks (subjects and communities) within the company, which may use different technologies and procedures (tools), work in multidisciplinary teams (division of labor) and be organized by collective traditions, rituals and norms (rules). 
The creation of the HE experience requires the construction of the core (co-created learning experience) and supplementary services (payment, campus facilities, staff helpfulness, response to inquiries) by the interaction of people, processes and physical evidence in different encounters (GRÖNROOS, 1990; NG; FORBES, 2009). As a result, we suggest the pedagogical experience activity system (e.g. lectures) is surrounded by different "neighbour activities" such as the supplementary services activity system (campus facilities, application processes, payment of fees, counselling services, etc); the administrative activity system (support processes, buying processes, human resources processes, etc); and the ideological and strategic activity system (resource allocation, philosophy, promise making, etc). In AT, activities are considered as object-oriented, artefactmediated, multi-voiced, historically evolved activities where equilibrium is an exception, in which transformative learning can take place through the analysis of its contradictions within. These activities are full of social interactions where value is co-created by the different actors (e.g. students, professors, directives, service personnel, stakeholders) of the system; These are an essential part of the HE experience, are achieved often via the service encounters. The unit of analysis of activity is the activity system, therefore the project proposes service encounters as activity systems. This connection between the main activity (the pedagogical experience activity system) and its "neighbor activities" (supplementary services activity system, administrative activity system, ideological and strategic activity system) produces inevitable contradictions that emerge in the moment of interaction. Contradictions are not the same as conflicts or problems, but historically accumulated structural pressures within and among activity systems. In other words, contradictions produce troubles and cracks, but also offer novel opportunities to transform the activity.

We propose AT as a potent socio-historical and socio-cultural lens through which it is possible to analyze power (division of labor) and political behavior (rules) and how these variables affect collaboration for value actualization in service encounters in HE institutions in Colombia. AT addresses notably that it is not possible to analyze or understand activity remote from the context in which it happens (JONASSEN; ROHRER, 1999). In this theory, activity is the entity of study which is composed of subject, object, actions and operations (NARDI, 1996); the activity is full of contradictions and disruptions within, acting as the heart and the driver for the system to change (MARKEN, 2006).

Front line providers of service in HE in Colombia, were asked to describe and report situations and incidents in which they became involved in political behavior practices, and to explain the power bases they used to reach cooperative outcomes to innovations and contradictions in service delivery. This design was aimed to capture social reality as constructed (BERGER; LUCKMANN, 1967). We explored contradictions among the different elements of the service encounter as an activity system and found predominantly conflicts for value actualization related to the clarity and coherence in processes, scripts, plans, and procedures; the presence of inflexible bureaucratic rules and procedures, and the absence of rules and evaluation models that stress community working; the highly fragmented division of labor; and the way how information flows from the ideological system to the remaining activity systems bringing lack of knowledge and recognition of courses of action which may bring collaboration and value actualization.

We have made a case for using AT concepts for the purpose of studying the service encounter as a social space with inner contradictions that lead to cracks and conflicts for power and control. Further we demonstrate that these contradictions and power play affect collaboration for value actualization in interactions, and potentially hinder development in HE in Colombia.

\section{Overview of relevant literature}

\section{The service encounter}

Most recently the service-dominant logic of marketing (VARGO; LUSCH, 2004) proposes service (in the singular) as a central concept for marketing, where a supplier offers a value proposition, but value actualization (GUMMESSON, 2007) occurs in the activities during the usage and consumption process as an outcome of co- 
creation between supplier and customer through knowledge renewal (BALLANTYNE; VAREY, 2006) in different service encounters. Service is considered as a process to the benefit of another party (VARGO; LUSCH, 2008a). Service encounters are primarily dynamic social encounters (CZEPIEL et al., 1985) in which consumers are looking for a solution to life's problems (ALDERSON, 1957). Furthermore, Gremler, Bitner and Evans (1994) called the interactions between employees within a firm as internal service encounters, finding that internal customers (employees) are similar to external customers in events and behaviors associated to satisfaction and dissatisfaction. Gummesson $(1999,2002)$ suggests that internal customers (employees) are a market within the enterprise which has to be directed efficiently to satisfy external customers' needs. For this purpose we focus in the service provider as an interactive entity for the activity system which has external (service delivery) and internal (service relationships) outcomes.

The transfer of individual knowledge to the organization cannot always be assumed since the relationship between employees and organizational learning is very complicated (BELL; MENGUC; WIDING, 2010).There are tensions in interpretations between individuals and organizations (CROSSAN; LANE; WHITE, 1999). Barriers are built up as bases for political manipulation by groups and players aiming for restricted resources (FRANWICK et al., 1994) with conflicting goals and priorities (RUEKERT; WALKER, 1987). Since these realities apply to the HE experience, which is proposed as the interaction of a main activity (pedagogical experience activity system) with its "neighbors activities" (supplementary services activity system, administrative activity system, ideological and strategic activity system); Political behavior and power appear as central organizational variables which can provide dynamic energy for organizational innovation and change (HARDY; CLEGG, 1996) and are important and inevitable aspects of any organizational reality (BUCHANAN; BADHAM, 1999).

\section{Power and political behavior}

Service encounters are social spaces where the most valuable networks of operant resources of the firm (customers and employees) act on other operant (customers, employees) and operand (machinery, procedures, rules) resources, to create value through service provision (LUSCH; VARGO, 2009) and then produce value actualization (GUMMESSON, 2007); they are also social spaces to share knowledge and produce knowledge renewal (BALLANTYNE; VAREY, 2006) by a joint journey through "the third space" (GUTIERREZ; RYMES; LARSON, 1995) which is "a place where two scripts intersect, creating the potential for authentic interaction to occur". For that reason, the goal for firms is to support operant resources' (internal and external consumers) value creation activities, since they are responsible for their own value creation. Value co-creation opportunities only exist if suppliers fulfill this role - carry out this facilitation. Therefore, service suppliers have to actually help (by facilitation) customers/clients to realize their value. If the service suppliers fails to act as a facilitator in the service encounter, this failure will prevent value actualization. What is it that leads to this failure? This brings as to consider the theme of power - positive use and negative use.

Why in a system where parties intend to exercise influence, such as the service encounter, would the supplier fail to perform this role? For we note that intra-organizational cooperation for value actualization in service encounters requires both trust and a good use of power (HARDY;PHILLIPS;LAWRENCE, 1998), the failure is due to negative power or absence of trust. To address the concern we draw from the literature on power.

Power is not unidirectional; it is multifaceted and shows up in numerous modes. Power relations are learned and become part of human being's identity as individuals take part in the practices of specific communities (FOUCAULT, 1977) cited in (GUTIERREZ; RYMES; LARSON, 1995). One issue is that the ways in which power has been researched have been managerially "modernist" in the extreme. Mainiero (1986), when reviewing the socialisation literature, found that the data on the use of reward, legitimate, coercion, and expert bases of power, and on gender difference in the perception of the exercise of these bases, "were primarily collected in laboratory situations, in which participants were asked to respond with their hypothetical reactions or perceptions. Few studies exist in which behaviour was observed" (p.636). Those studies that exist, such as Gaski and Nevin, (1985) are in the research area of channel conflict. Inevitably it is the "hard" power bases 
that are researched. The "soft" bases include: informational power, (RAVEN; KRIGLANSKI, 1970), referent, legitimate and expert power. Of these five or six sources of power, only two have been thoroughly researched since only two have clear objectivity (HOPKINSON, 1998). Gaski and Nevin's discussion of exercised and unexercised power (1985) is applied to reward and coercive power only.

Politics and the use of power appear then as central organizational variables which can provide dynamic energy for organizational innovation and change (HARDY; CLEGG, 1996) and are important and inevitable aspects of any organizational reality. Power refers the competence of human beings to exercise their will over others and political behavior is the practical field of power in action, put to work through practices of influence and other (more or less) severe tactics; additionally, power can also be identified as a property of individuals, a property of relationships or an embedded property (BUCHANAN; BADHAM, 1999) and politics could also be defined as the use of power to encourage interests, so there could be as many types of politics as there are categories of power (BAUM, 1980). Political behavior has been traditionally seen in a negative way and associated to the creation of inflexibilities, communicational barriers, restriction of information (EISENDHART; BOURGEOIS, 1988) Mayes and Allen (1977) defined as the means which one organization player uses to influence others to achieve their preferred outcomes; both the means and the ends or outcomes pursued may or may not be organizationally sanctioned, the limitation of this approach is to knows who decides what is sanctioned and what is not (BUCHANAN; BADHAM, 1999) Harrison (1987) cited in (BUCHANAN; BADHAM, 1999) posited that political behaviour can complement "legitimate" management actions such as the use of otherwise legitimate means to non-legitimate ends such as unreasonable assertions of authority by managers, the removal of bureaucratical blockages raised by the legitimate system, smooth the progress of the implementation of decisions reached by legitimate means; make explicit all the dimensions of an argument; and help actors develop political capabilities and skills to deal with intrigues and power-plays . Furthermore, political forces can also be seen as a critical resource of dynamic force for organizational change (HARDY, 1996).

\section{Activity theory as a framework for service encounters}

Activity Theory (AT) conceives psychological development as a practice of social interaction within specific cultural and historical contexts (VYGOTSKY, 1978). Activity Theory (AT) inferences a systemic view of human behavior in which an individual's goals and subjective perceptions are inter-related with socio historical factors within its relevant environmental context, which argues that (JONASSEN; ROHRER, 1999) "conscious learning emerges from activity (performance), not as a precursor to it"; as a result when investigating human activity, it is important to see not just the activities people engage in but also who is engaging in any activity, what are their intentions and goals, what are the products (objects) which result from that activity, the norms and rules which restrict that activity and the larger community involved in that activity, all of them parts of the activity system (JONASSEN; ROHRER, 1999). Interaction offers an interpretive source from which actors assign meaning to their individual and other actors actions, so they can engage in collective activity (VYGOTSKY, 1978).

First generation of Activity Theory (AT) thinkers, pioneered by Vygotsky, stated that the link between an stimulus and a response was surpassed by a complex intervening act, introducing mediation as its core idea (ENGERSTRÖM, 2001). Furthermore, a second generation group of activity theory thinkers headed by Leont 'ev went beyond the individual analysis proposed by Vygotsky, explaining the difference between individual actions and collective activities (ENGERSTRÖM, 2001). Engerström posited that Vygotsky's claims may work for animals but for humans the situation is more complex and different (MARKEN, 2006). Sketching from evolutionary biology from Lewontin's dialectical interaction between organism and environment, Engerström suggested that individual survival was mediated by artifact making; social life was mediated by collective rules, traditions and rituals; and collective survival was mediated by the emergence of a division of labor (ENGERSTRÖM, 1999). Developments in activity theory have brought a third generation that is in search of conceptual tools which can help understand dialogue, perspective of multiple actors, and networks or groups of activity systems that are constantly interacting (ENGERSTRÖM, 2001). Third generation of AT expands it analysis both up and down and outward and inward covering interrelated activity systems with 
partially shared and split objects, as well as, issues of subjectivity, emotion, identity, experiencing, and moral commitment (ENGERSTRÖM, 2009). Engerström ( 2001) summarized the framework for AT, into five different principles, which are: collective artifact-mediated and object-oriented activity systems in its network relations as a primarily unit of analysis; multi-voicedness of the activity system; historicity; the role of contradictions; and the possibility of expansive learning.

Collective activity is practical, and is performed aiming to get an outcome in activity systems (ENGERSTRÖM, 2000). The activity system is the major entity of analysis in AT and it is defined by Engerström and Miettinen (1999) as "object-oriented, collective and culturally mediated human activity" . An activity system, as proposed by Russell (1997), is the basic unit of analysis of individual or collective behavior of any human interaction characterized by being, historically-conditioned, tool-mediated, dialecticallystructured and object-directed: an organization, a political movement, a classroom, a consumer etc. The activity system is full of contradictions and disruptions within, acting as the heart and the driver for the system to change (MARKEN, 2006) These contradictions or disruptions can be presented in four different levels: level 1: with the subject itself; level 2: between two different elements of the system; level 3: between the object and the motive; or level 4: between different systems (MARKEN, 2006). In this project we aim to find level 2 contradictions with the idea of looking for "harmony" within the system and level 4 contradictions since is familiar in bureaucracies that activities of one part of the system are in conflict with the activities or another system.

The activity system contains the interacting elements or nodes of subject, object, mediating artifacts (tools or instruments), community, division of labor, rules and outcome (MURPHY; RODRIGUEZ-MANZANARES, 2008).

Figure 1: The structure of human activity: the activity system

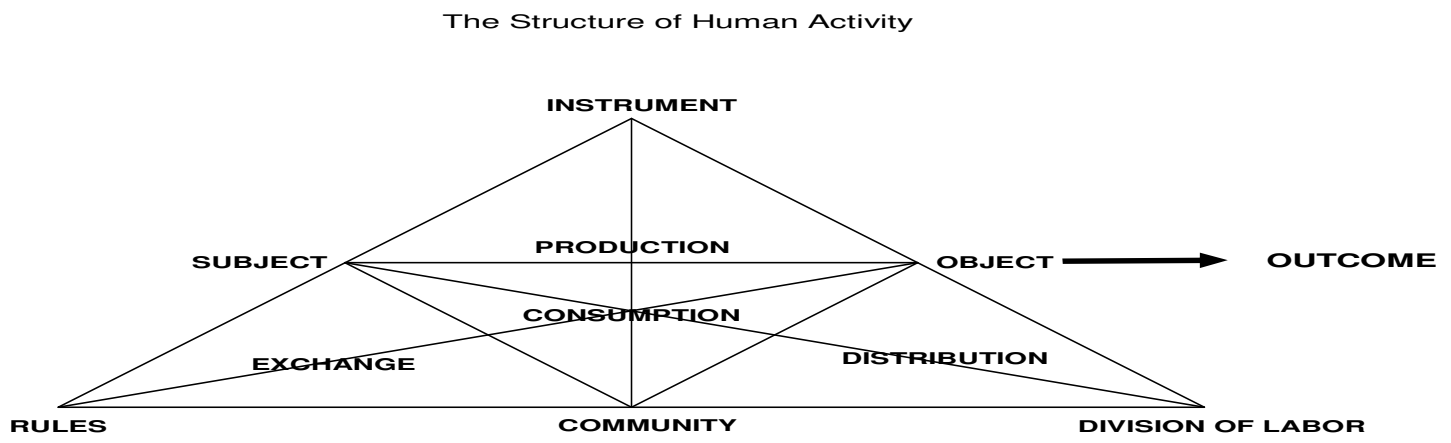

The subject of an activity system is the individual or group whose view point is adopted (MURPHY; RODRIGUEZ-MANZANARES, 2008; is the actor or group of actors engaged in an activity (JONASSEN; ROHRER, 1999). In other words, the subject is who performs the action, the doer. Usually the subject is an individual, but sometimes could be a group, based on the level and type of analysis which is going to be done (MARKEN, 2006).

- The object of an activity system pertains to the "raw material" or "problem space" at which the activity is aimed at and which is transformed into outcomes with the help of mediating tools or 
artifacts (BOER; VAN BAALEN; KUMAR, 2002). The object shows a motivational or determined character of human activity which lets humans to control their personal behavior (MWANZA, 2001). It precedes and motivates activity (MURPHY; RODRIGUEZ-MANZANARES, 2008). However, since the object as the "true motive" in Activity Theory (AT) is frequently merged with the objective of the activity, Marken (2006) conceived the object as "that which the activity system was acting upon, which one hopes will change as a result of the activity system working as it should". We utilized this approach in our study.

- The outcome of an activity system goes after the object, and is closer to what individuals believe of an objective is. As a consequence of the elements of the activity system acting upon an object, there is an outcome. The outcome is therefore a consequence from transformations in the object (MARKEN, 2006).

- Tools, mediating artifacts, or artifacts mediate the object of activity (MURPHY; RODRIGUEZMANZANARES, 2008). They can be anything employed in the transformation practice, and they could be external or physical, such as a textbook, or a computer; or conceptual, internal, mental or symbolic, such as, language, procedures, or models (JONASSEN; ROHRER, 1999; MARKEN, 2006; MURPHY; RODRIGUEZ-MANZANARES, 2008; MWANZA, 2001). Physical artifacts are utilized to handle or manage objects, while conceptual artifacts are utilized to influence behaviors in different ways (MWANZA, 2001). Artifacts play a part in the transformation of the object into an outcome, which could be preferred or unpredicted. They may facilitate or restrain activity (MURPHY; RODRIGUEZ-MANZANARES, 2008) and play a crucial role in shaping the way human beings act and think (JONASSEN; ROHRER, 1999).

- Community pertains to the actors and multiple individuals or subgroups, who share the object (MURPHY; RODRIGUEZ-MANZANARES, 2008) and a set of social meanings (JONASSEN; ROHRER, 1999) in an activity system, and who also construct themselves as different from other groups (BOER; VAN BAALEN; KUMAR, 2002) ; in short, the stakeholders of the system (MARKEN, 2006). The "community" element in the model locates the analysis of the activity which is under scrutiny, into the cultural and social background of the environment where subjects operate, reaffirming the appropriateness of Activity Theory (AT) in the revision of human performances within and among organizations (MWANZA, 2001). The community may also be considered as the other actors who provide a circumstance for the task the subject is going through (MARKEN, 2006).

- The division of labor engages the separation of different tasks and roles among individuals of the community and the division of power and status (MURPHY; RODRIGUEZ-MANZANARES, 2008). In every activity system, always progresses or is created a way of dividing the labor for the object to be developed (MARKEN, 2006), stipulating the task specialization by the members of the community of an activity system (JONASSEN; ROHRER, 1999). Tasks are usually divided horizontally and power and status vertically (BOER, VAN BAALEN; KUMAR, 2002). This element of the activity system refers to the allocation of responsibilities and changes in job roles of the subjects as they perform an activity in the community (MWANZA, 2001). The division of labor also mediates, restrains and reasserts action (MARKEN, 2006).

- The rules are the norms that control actions and interactions contained by the system (MURPHY; RODRIGUEZ-MANZANARES, 2008). Rules might be written (accreditation, standards, workplace values) or unwritten (cultural norms and values), and both of them restrain and warrant action since they "govern" what the subject is able to do when using the different artifacts (MARKEN, 2006). Rules intrinsically direct, at the least in some extent, the actions or activities tolerable for the community, so the artifacts, symbols, methods, procedures, and signs that are utilized by the community mediate the process (JONASSEN; ROHRER, 1999). Rules affect in one way or another the means by which an activity is being operated (MWANZA, 2001). 


\section{The service encounter as an activity system}

The service encounter is an artifact-mediated (e.g. scripts, practices, organizational norms, political behavior, roles) and object oriented (e.g. a solution of a problem, doing something for the benefit of another party). Consumers view solutions as a set of relational processes (TULI; KOHLI; BHARADWAJ, 2007). Interactions, on the other hand, have been traditionally approached by the Nordic School of Management being a central construct in relationship marketing (GRÖNROOS, 2008d; GUMMESSON, 2002) and in service marketing in the form of interactive marketing (GRÖNROOS, 2008b; GRÖNROOS, 2008c), interaction quality (LEHTINEN; LEHTINEN, 1991) and the role of part-time marketers (GUMMESSON, 1991). Grönroos (2008a) posited that in general, terms: "interaction is mutual or reciprocal action where two or more parties have an effect upon one another" in a business context "supplier-customer interactions mean that two or more parties are in contact with each other for a commercial reason, and in these contacts they have opportunity to influence one another's processes". In looking at the interaction from the value creation perspective the situation users are in charge of the process and suppliers are the ones who are invited to engage with consumers' value generating processes in order to support users' value fulfillment in those processes (GRÖNROOS, 2008a). During these interaction suppliers can actively influence the flow and outcome of users' value generating processes, however they are not the value creator (since the customers are the ones who create value) but a value facilitator and co-creator of value as well. Co-creation opportunities that suppliers have are strategic alternatives for constructing value (PAYNE; STORBACKA; FROW, 2008), in interactions that should produce dialogical moments, where both actors should be active in a learning process and influence each other's actions, activities, and perceptions (BALLANTYNE, 2004; BALLANTYNE; VAREY, 2006), in a true joint value co-creation process in which both actors are engaged and perform as expected (GRÖNROOS, 2008a).

Furthermore, service encounters can be considered as multi-voiced since they are systems that involve communities with numerous different points of view, interests, objectives, and customs where actors (operant resources) bring their own different stories based on different roles produced by the division of labor. Therefore, we view them as a site of conflict for power and control (BATESON, 1985) where social identities are anchored and collective meanings are constituted and reproduced. The examination of the horizontal relationship between the service user and the service provider should prevent the vertical power (division of labor, roles) in the value facilitation process of the company from turned into a dead end.

Relationships between service providers and service user are restricted by rules (e.g. organizational credo, political behavior) which govern what the actor (operant resource) can and cannot do to shape the object (e.g. offer a value proposition, solve one of life's problems) by the use of artifacts (e.g. procedures, scripts, promises) which work as effective vehicles to transport agreements among the actors (BLACKLER, 1993). In these interactions among the different actors within the value facilitation system, and the value co-creation system which are mediated by the artifacts, rules, and division of labor will appear inevitable break downs and contradictions that would make the actors reconceptualize the rationale in which the activities (value facilitation, value co-creation) occur. Contradictions are not the identical to conflicts or problems. Contradictions come from the historical accumulation of structural pressures inside and among activity systems. The main contradiction in capitalism is fixed between the exchange value and use value of commodities (ENGERSTRÖM, 2001). Commodity is an object which has intrinsic value (i.e. exchange value), not only and not principally use value (ENGERSTRÖM, 1999). This main contradiction passes through all components of societies' activity systems. Since activities are open systems, when activity systems employ an innovative element from the exterior (e.g. new knowledge or a new tool), it frequently leads to an intensified level 2 contradiction where an earlier element (for example, the division of labor or the rules) crashes with the innovative one. These contradictions produce troubles and divergences, but also novel efforts to transform the activity (ENGERSTRÖM, 2001). Since activity systems progress through relative extended cycles of qualitative changes, contradictions within the activity systems get worse, and a number of individual partakers (operant resources) in the activity start to call into question the operations and actions in the activity system, 
and move away from its recognized rules (operand resources). In some instances, these changes grow into shared visualization and a purposeful cooperative transformational effort. When the object and the motive of the activities are reconceived to adopt a much larger scope of possible actions than the preceding method of the activity, an expansive transformation takes place. As an example of co-creation of value in a service encounter we can see that an object progresses from an opening state of situationally given "untreated material" (object 1 e.g. a student entering into a meeting with a professor) to a collectively meaningful object constructed by the activity system (object 2 e.g. the student constructed as a mere academic category and thus as a representation of an evaluation of an assignment), and to a potentially shared or jointly constructed object (object 3 . e.g. a collaboratively constructed understanding of the student's assignment situation and a making of a shared project plan to understand scientifically the activity).

Gummesson (2006) suggests that marketing and society is about relationships, networks and interaction. In this view, service encounters as activity systems can be proposed as:

- a system which main outcome is the co-creation of value by the interaction of its active operant resources knowledge (communities, consumers, providers) that are looking for solutions of one of life's problems (e.g. service providers offer a value proposition, service user uses a determined value proposition) and which is mediated by artefacts, rules and roles which act as enablers or barriers for service provision.

- a system of multi-voiced polyadic interactions among the different elements (nodes) of the network with routinely tensions and disturbances which are the source of expansive learning trough action

- a system of networked relations between organizational and consumption communities of activity which seek for solutions through inter-collective interaction

- activities that are culturally, historically and socially contextualized phenomena in which dialogue should act as a tool, reciprocity as a rule and the good use of power as division of labor which then serve as mediators to produce a collaborative conscious knowledge renewal and thus service provision.

To conclude this review of the service encounter as an activity system we propose a third generation of activity theory to understand the service encounter as an activity system from the Service-Dominant logic (S-D) perspective (see figure 2), and for this article purposes we will focus on how the specific elements or nodes of division of labor (power), and rules (political behavior) affect collaboration for value actualization in service encounters in a HE institution in Colombia. The angular stone of the S-D logic is that firms, markets and societies are essentially and continually involved in the process of exchanging service, which is, the act of doing something for the benefit of another party (VARGO; LUSCH, 2008b), and which is for the most part focused on operant resources (dynamic resources such as skills and knowledge that can act on other tangible, static, operand resources) (VARGO; LUSCH, 2008a). Nevertheless, service all the time entails the beneficiary as an active element of the service (LUSCH; VARGO, 2009). Therefore, the main object of a service encounter as a system is the co-creation of value in interactions, however not all service system interactions can be considered as service interactions (SPOHRER et al., 2008). 


\section{Figure 2: The service encounter as an activity system}

\section{The Service Encounter as an Activity System}

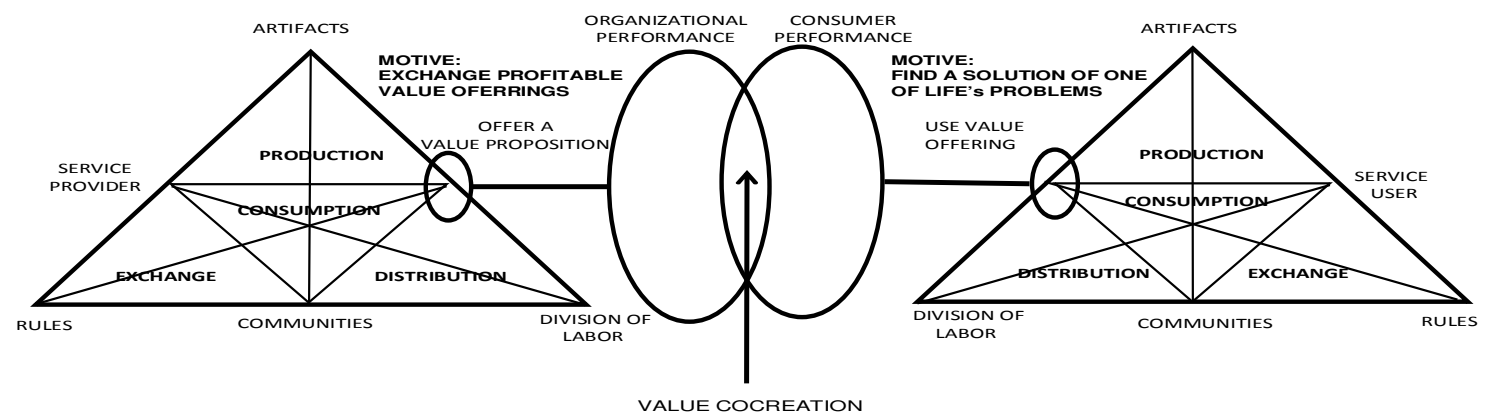

Source: the authors

\section{Methodology}

\section{Research question}

Our immediate research question is how does the use of AT as a framework for the service encounter in HE shed light on the Service Encounter as site of conflict of interests, of legitimate and less legitimate ends and the practice of power? Our bigger picture question is how does this process help or hinder HE institutional development in Colombia?

\section{Research design}

Front line providers of service in HE in Colombia, were asked to describe and report situations and incidents in which they became involved in political behavior practices, and to explain the power orientations they used to reach cooperative outcomes to innovations and contradictions in service delivery. This design is aimed to capture social reality as constructed (BERGER; LUCKMANN, 1967) by means of narratives from service providers responding to questions we will draw up from the literature, in a continuous story of their experiences. The analytical process can be broken into the three categories: description, analysis and interpretation. However, we understand that these three are not clearly distinct, for it is also the case that 'implicit analyses or interpretations gradually give way to explicit ones, in even the most descriptively oriented account' (WOLCOTT, 1994). A total of 7 interviews were collected from secretaries, lecturers, researchers, program leaders and administrative assistants all of them involved in service provision in service encounters.

To develop questions we used Mwanza's research (MWANZA, 2001).

Mwanza reorganizes AT Engerström's triangles by taking the elements of activity systems from their position in the diagram, and as an alternative shows them as sub-activity mediated combinations of the actors or doers and the purposes or objectives (MWANZA, 2001) (see table 1) 
Table 1: Activity notation (MWANZA, 2001)

\begin{tabular}{ccccc}
\hline Actors (Doers) & \multicolumn{3}{c}{ Mediator } & Objective (Purpose) \\
\hline Subjects & - & Tools & - & Object \\
\hline Subjects & - & Rules & - & Object \\
\hline Subjects & - & Division of Labor & - & Object \\
\hline Community & - & Tools & - & Object \\
\hline Community & - & Rules & - & Object \\
\hline Community & - & Division of Labor & - & Object \\
\hline
\end{tabular}

This leads to six general inquiries (MWANZA, 2001) which are:

- What tools do the subjects use to achieve their objective and how?

- What rules affect the way subjects achieve the objective and how?

- How does the division of labour influence the way subjects satisfy their objectives?

- How do the tools in use affect the way the community achieves the objective?

- What rules affect the way the community satisfies their objective and how?

- How does the division of labour affect the way the community achieves the objective?

The main objective for our study was to explore how power play affects collaboration for value actualization in service encounters and to analyze and interpret contradictions within and among the elements or nodes of the activity systems; specially focusing on the mediating elements (rules, artifacts and division of labor)

The activity for the study was identified and named as collaboration in the Colombian HE service encounter; and the object was identified as contradictions and power play for value actualization in the Colombian HE experience. The subjects involved in this activity were identified as front-line providers of the Higher Education experience in a specific educational institution in Colombia.

The main idea was to collect data on collaboration as a means to development. Views on how the respondents worked were elicited. Interviewees were asked to propose the tools and the rules that enable them to affect the subject (i.e. ISO, action plans, scripts). Concrete incidents of power play (division of labor) were sought. Together this added up to the great picture of collaboration for value actualization in service encounters.

\section{Findings}

\section{Description}

The interviewees were reluctant to tell histories about power-related issues for finding solutions in service encounters and instead decided to answer briefly and without reflexivity on how mediators in the organization affect collaboration in practice. Respondents supplied answers on how rules, tools and division of labor should act to produce collaboration for finding solutions in service encounters, instead of focusing on how those practices are being handled at this moment within the organization.

Six respondents simply answer the questions briefly, which only let us find level 2 contradictions (between two different elements of the system) in the activity system. The identified areas of contradictions were mapped into activity systems and are summarized in the figure 3 . 
Figure 3: Contradictions for cooperation to find solutions in SE in HE in Colombia

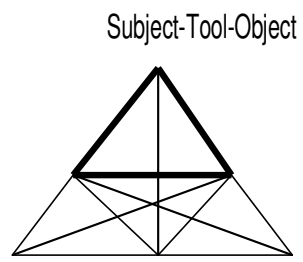

Subject-Rules-Object

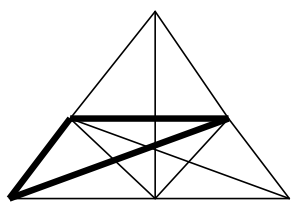

Subject-Division of Labour-Object

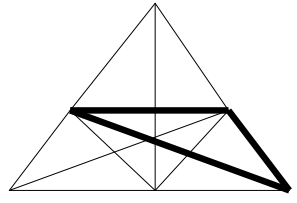

Community-Tool-Object
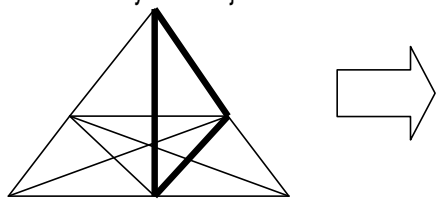

Community-Rules-Object
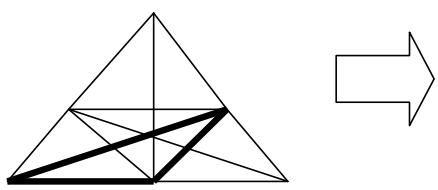

Community-Division of Labour-Object
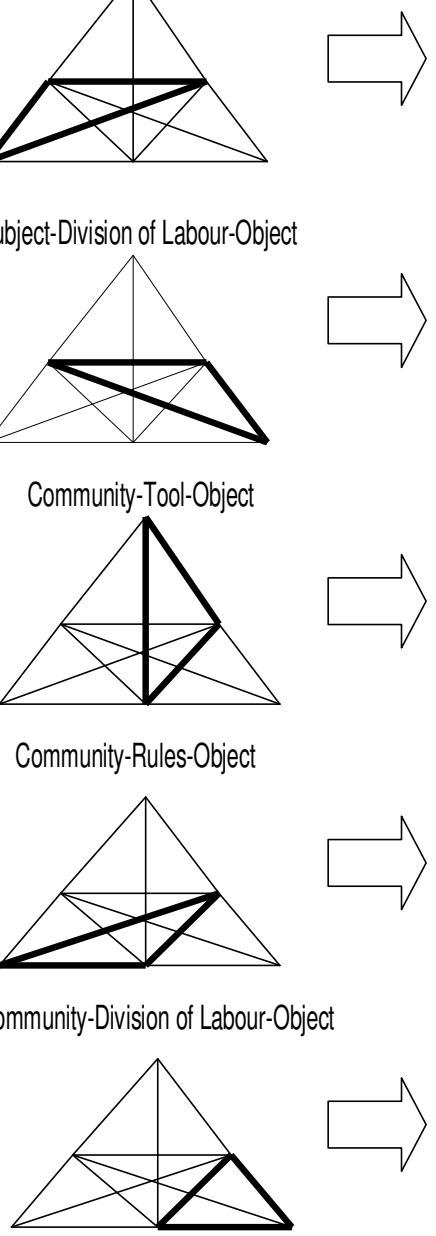

\section{QUESTIONS GENERATED FOR THE STUDY}

IDENTIFIED AREA OF CONTRADICTION

How do the tools (procedures, scripts, ISO) help actors to cooperate in finding solutions about work so as to provide better customer (internal-external) experience?

rchy on cooperation in finding solutions about work so as to provide better customer (internal-external) experience?

How does the use of rules help actors to cooperate in finding solutions about work so as to provide better customer (internalexternal) experience?

Does the organization's use of the evaluation system affect the way actors cooperate in finding solutions about work so as to provide better customer experience?

How does the operational structure affect actors in cooperating in finding solutions about work so as to provide better customer (internal-external) experience?
- Lack of clarity in processes

$\longrightarrow$-Lack of knowledge and recognition about practices, scripts, plans, and procedures

-Delays in getting things done and to fulfil the requirements asked for the process and norm (ISO)

-Inflexible bureaucratic rules - Rules don't stress team and community working

- Everything in writing -Use of different communicational tools among the communities (e-mail, webCT and lotus)

- No impact of performance evaluations, they are seen as an institutional rule rather than an organizational performance evaluation

- Highly fragmented division of labor

$\rightarrow$ Cooperation depends on the place of the person in the hierarchy

From the remaining interview, the only narrative we obtained, we identified a level 4 contradiction (see figure 4) between the activity system which creates the rules (ideological system) and the way this rules flow to the remaining activity systems (pedagogical, supplementary services and administrative system) and become artifacts, causing conflicts in how the subjects and the communities use the artifacts to transform the object of the activity, in this case collaboration for value actualization. 
"the scripts, procedures and action plans have the weakness of not being recognized by the whole educational community, therefore, their effects to boost cooperation to provide solutions to institutional problems do not make them as a first hand tool for all the members of the educational community. It is possible that those tools are much more recognized by administrators and members of the staff for which the knowledge of procedures and manuals is part of their job function" (interviewee 7, researcher)

Figure 4:. Power relations in service encounters in the HE experience. Compulsory rules implemented by the ideological system.

\section{Power Relations in Service Encounters in the HE Experience}

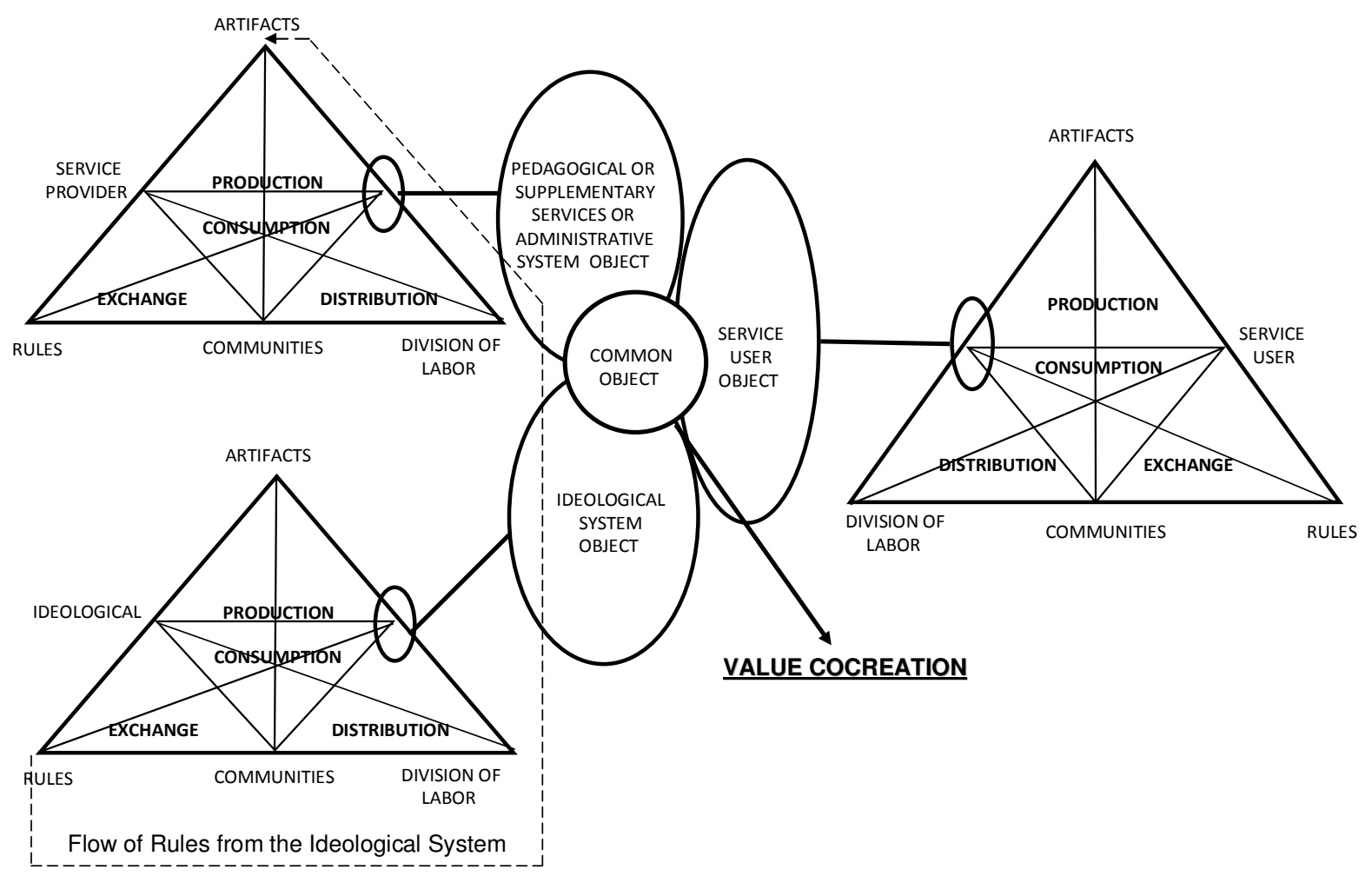

\section{Interpretation}

We found contradiction in the organization's method for making the rules (action plan) by the ideological system and how these rules flow to become the artifacts (procedures, processes) in the other activity systems in the organization. Procedures and plans are not being recognized by the entire community since they are communicated by tools (Lotus Notes instead of E-mail) which are not used by the entire community but only by the administrative and ideological systems, so they just become a useful tool for employees who work in administrative divisions of the institution since they are part of their daily basis job. Indeed, nothing is authorized unless is in writing but the status of an e-mail over the lotus notes communication is unclear. This restrains collaborative actions among the administrative systems and the pedagogical since communication does not flow efficiently among those systems.

Furthermore, the interviewees recognized that tools help to diminish the waiting time for requests; however the administrative process of using them is still complex and bureaucratic and recognized as inflexible and even 
meaningless. This situation creates conflicts between the communities and subjects with the tools, and hinders collaboration in finding collaborative solutions for problems.

The absence of rules that promote collaborative team work and the way the performance evaluations are being used, drive the focus on solving problems in an individual manner rather than in a collaborative way. There is therefore an absence of a "service culture" and the organization is not seen as a whole system that works to solve problems, but rather as a group of different individual functions, hindering value actualization in service encounters. This also creates inner contradiction for employees of feeling as a part of a team or as mere wage earners who are carrying out isolated functions.

\section{Conclusions}

We have made a case for using AT concepts for the purpose of studying the service encounter as a social space with inner contradictions that lead to cracks and conflicts for power and control. Further we demonstrate that these contradictions and power play affect collaboration therefore value actualization in interactions, and hinder institutional development in HE in Colombia.

We demonstrated that contradictions among the doers (subjects and community) with its organizational rituals, procedures and the way in which solutions are separated by task specialization restrain action and collaboration in service encounters in the HE studied in Colombia. Furthermore, the way in which rules are created and the flow of those created rules from the ideological system to the remaining activity systems in the organization, hinder collaboration since rules are not properly shared with the entire community causing lack of recognition of them and hindering value actualization in service provision.

We recommend further studies should narrow the respondent's attention to delimit further the activity of study, (i.e., the design of an " $\mathrm{X}$ " academic program) and use approaches that share characteristics of action research. This is to respond the need to develop trust with the participants of the study to obtain more fruitful and reflective insight. We need then to produce genuine narratives rather to mere question/answer responses. 


\section{References}

ALDERSON, W. Marketing behavior and executive action: a functionalist approach to marketing theory. Homewood, IL: Richard D. Irwin, Inc., 1957.

BALLANTYNE, D. Dialogue and its role in the development of relationship specific knowledge. Journal of Business and Industrial Marketing, v.19, n.2, p.114-123, 2004.

; VAREY, R. Creating value-in-use through marketing interaction: the exchange logic of relating, communicating, and knowing. Marketing Theory, v. 6, n.3, p.335-348, 2006.

BATESON, J. Perceived control and the service encounter. In: CZEPIEL, J.; SOLOMON, M.; SURPRENANT, C. (Ed.). The service encounter: managing employee/customer interaction in service businesses. Lexington, MA: Lexington Books, 1985.

BAUM, H. S. Organizational politics against organizational culture: a psychoanalytic perspective. Human Resource Management, v.28, n.2, p.191-206, 1980.

BELL, S.; MENGUC, B.; WIDING, R. Salesperson learning, organizational learning and retail store performance. Journal of the Academy of Marketing Science, v.38, n.2, p.187-201, 2010.

BERGER, P. L.; LUCKMANN, T. The social construction of reality. Harmondsworth: Penguin Books, 1967.

BLACKLER, F. Knowledge and the theory of organizations: organizations as activity systems and the reframing of management. Journal of Management Studies, v.30,n.6, p.863-884, 1993.

BOER, N.; VAN BAALEN, P.; KUMAR, K. An activity theory approach for studying the situatedness of knowledge sharing, In: Proceedings of the $35^{\text {th }}$ Hawaii International Conference of Systems Science, Waikoloa, Big Island, Hawaii, USA, p.1-10, January, 2002.

BUCHANAN, D.; BADHAM, R. Power, politics and organizational change: wining the turf game. London: Sage Publications, 1999.

CROSSAN, M. M.; LANE, H. W.; WHITE, R. E. An organizational learning framework: from intuition to institution. Academy of Management Review, v.24, n.3, p.522-537, 1999.

CZEPIEL, J.et al. Service encounters: an overview. In: CZEPIEL, J.; SOLOMON, M.; SURPRENANT, C. (Ed.). The service encounter: managing employee/customer interaction in service businesses. Lexington, MA: Lexington Books, 1985.

EISENDHARDT, K. M.; BOURGEOIS, L. J. Politics and strategic decision making in high-velocity environments: towards a mid-range theory. Academy of Management Journal, v.75, n.4, p.737-770, 1988.

ENGERSTRÖM, Y. Introduction. In: LEARNING by expanding: ten years after. German edition. Marburg, Germany: BdWiVerlag, 1999.

. Activity theory as a framework for analizing and redesigning work. Ergonomics, v.43, n.7, p.960-974, 2000.

. Expansive learning at work: toward an activity theoretical reconceptualization. Journal of Education at Work, v.14, n.1, p.133-156, 2001.

. The future of activity theory: a rough draft. In: SANNINO, A.; DANIELS, H.; GUTIERREZ, K. D. (Ed.). Learning by expanding with activity theory. Cambridge, UK: Cambridge University Press, p.303-328, 2009.

; MIETTINEN, R. Introduction. Activity theory: a well-kept secret. In: ; PUNAMAKI, R. (Ed.). Perspectives on activity theory. Cambridge, MA: Cambridge University Press, 1999.

FOUCAULT, M. Discipline and punish: the birth of a prison. London: Allen Lane, 1977.

FRANWICK, G. L. et al. Evolving patterns of organizational beliefs in the formation of strategy. The Journal of Marketing, v.58, n.2, p.96-110, 1994.

GASKI, J. F.; NEVIN, J. R. Power sources the differential effects of exercised and unexercised in a marketing channel. Journal of Marketing Research, v. 22, n.2, p.130-142, 1985.

GREMLER, D.; BITNER, M. J.; EVANS, K. The internal service encounter. International Journal of Service Industry Management,v.5, n.2, p.34-56, 1994.

GRÖNROOS, C. Service management and marketing: managing the moments of truth. Lexington, MA: Lexington Books, 1990. 
. Adopting a service business logic in relational business-to-business marketing. In: Otago Forum 2 The ServiceDominant Logic for Marketing: from Propositions to Practice, Dunedin, New Zealand, December, pp. 269-287, 2008a.

Adopting a service logic for marketing. In: (Ed.). In search of a new logic for marketing: foundations of contemporary theory. Chichester, West Sussex: John Wiley and Sons, Ltd., 2008b.

An applied service marketing theory. In: (Ed.). In search of a new logic for marketing: foundations of contemporary theory. Chichester, West Sussex: John Wiley and Sons, Ltd., 2008c.

The relationship marketing process: communication, interaction, dialogue, value. In: (Ed.). In search of a new logic for marketing: foundations of contemporary theory. Chichester, West Sussex: John Wiley and Sons, Ltd., 2008d.

GUMMESSON, E. Marketing-orientation revisited: the crucial role of the part-time marketer. European Journal of Marketing, v.25, n.2, p.60-75, 1991

. Total relationship marketing: rethinking marketing management-from 4Ps to 30Rs. Oxford: Butterworth-Heinemann, 1999.

Total relationship marketing: marketing management, relationship strategy and CRM approaches for the network economy. $2^{\text {nd }}$ ed. Oxford: Butterworth Heinemann, 2002.

Many-to-many marketing as grand theory. In: LUSCH, R.; VARGO, S. (Ed.). The service dominant logic of marketing: dialogue, debate and directions. Armonk, NY: M. E. Sharpe Inc., p.339-353, 2006.

Exit services marketing, enter service marketing. Journal of Customer Behaviour, v.6, n.2, p.113-141, 2007.

GUTIERREZ, K. D.; RYMES, B.; LARSON, J. Script, counterscript, and underlife in the classroom: James Brown versus Brown v. Board of Education. Harvard Educational Review, v.65, n.3, p.445-471, 1995.

HARDY, C. Understanding power: bringing about strategic change. British Journal of Management Special, issue7, p.S3S16, 1996.

; CLEGG, S. Some dare call it power. In: CLEGG, S.; HARDY, C.; NORD, W. R. (Ed.). Handbook of organizational studies. London: Sage, 1996.

; PHILLIPS, N.; LAWRENCE, T. Distinguishing trust and power in interorganizational relations: forms and facades of trust. In: Trust within and between organizations. LANE, C.; BACHMANN, R. (Ed.). Oxford: Oxford University Press, 1998.

HARRISON, E. F. The management decision-making process. Boston, MA: Houghton Mifflin, 1987.

HOPKINSON, G. C. An analysis of conflict in a franchised car distribution network. PhD Thesis, University of Bradford,1998.

JONASSEN, D; ROHRER, L. Activity theory as a framework for designing constructivist learning environments. Educational Technology Research and Development, v.47, n.1, p.61-79, 1999.

LEHTINEN, U.; LEHTINEN, J. R. Two approaches to service quality dimensions. The Service Industries Journal, v.11, n.3, p.287-303, 1991.

LUSCH, R.; VARGO, S. Service-dominant-logic- a guiding framework for inbound marketing. Marketing Review St.Gallen, v.26, n.6, p.6-10, 2009.

MAINIERO, L. Coping with powerlessness: the relationship of gender and job dependency to empowerment-strategy use. Administrative Science Quarterly, v.31, n.4, p.633-653, 1986.

MARKEN, J. An application of activity theory. Performance Improvement Quarterly, v.19, n2, p.27-50, 2006.

MAYES, B. T.; ALLEN, R. W. Toward a definition of organizational politics. Academy of Management Review, v.2, n.4, p.672-678, 1977.

MURPHY, E.; RODRIGUES-MANZANARES, M. Using activity theory and its principle of contradictions to guide research in educational technology. Australasian Journal of Educational Technology, v.24, n.4, p.442-457, 2008.

MWANZA, D. Where theory meets practice: a case for an activity theory based methodology to guide computer system design. In: Eight IFIP TC 13 Conference on Human-Computer Interaction, Tokyo, Japan, July, 2001. 
NARDI, B. Studying context: a comparison of activity theory, situated action models and distributed cognition. In: NARDI, B. (Ed.). Context and consciousness: activity theory and human computer interaction. Cambridge, MA: MIT Press, p.35-52, 1996.

NG, I. C. L.; FORBES, J. Education as a service: the understanding of university experience through the service dominant logic. Journal of Marketing of Higher Education, v.19, n.1, p.38-64, 2009.

PAYNE, A.; STORBACKA, K.; FROW, P. Managing the co-creation of value. Journal of the Academy of Marketing Science, v.36, n.1, p.83-96, 2008.

RAVEN, B. H.; KRUGLANSKI, A. W. Conflict and power. In: SWINGLE, P. (Ed.). The structure of conflict, New York, NY: Academic Press, 1970.

RUEKERT, R.; WALKER, O. C. J. Interactions between marketing and R\&D departments in implementing different business strategies. Strategic Management Journal, v.8, n.3, p.233-248, 1987.

RUSSELL, D. Rethinking genre in schools and society: an activity theory analysis. Written Communication, v.14, n.4, p.504554, 1997.

SPOHRER, J. et al. The service system is the basic abstraction of service science. In: $41^{\text {st }}$ Hawaii International Conference on Systems Science, Waikoloa, Big Island, Hawaii, USA, p.1-10, January, 2008.

TULI, K.; KOHLI, A.; BHARADWAJ, S. Rethinking customer solutions: from product bundles to relational processes. The Journal of Marketing, v.71, p.1-17, July 2007.

VARGO, S.; LUSCH, R. Evolving to a new dominant logic for marketing. The Journal of Marketing, v.68, n.1, p.1-17, 2004.

. Service-dominant logic: what it is, what it is not, what it might be. In: LUSCH, R.; VARGO, S. (Ed.). The service dominant logic of marketing: dialogue, debate and directions. Armonk, NY: M.E. Sharpe, p.43-56, 2006.

2008a.

Service dominant logic: continuing the evolution. Journal of the Academy of Marketing Science, v.36, n.1, p.1-10,

Why "service"? Journal of the Academy of Marketing Science, v.36, n.1, p.25-38, 2008b.

VYGOTSKY, L. S. Mind in society: the development of higher psychological processes. Cambridge, MA: Harvard University Press, 1978.

WOLCOTT, H. Transforming qualitative data. Thousand Oaks, CA: Sage, 1994. 